\title{
Can a change in cropping patterns produce water savings and social gains: A case study from the Fergana Valley, Central Asia
}

\author{
Akmal Kh. Karimov ${ }^{1 *}$, Munir A. Hanjra ${ }^{2}$, Jiří Šimůnek ${ }^{3}$, Botir Abdurakhmannov ${ }^{4}$ \\ ${ }^{1}$ International Water Management Institute (IWMI), Central Asia Regional Office, Tashkent, Uzbekistan. \\ ${ }^{2}$ International Water Management Institute (IWMI), Southern Africa Regional Office, Pretoria, South Africa. \\ ${ }^{3}$ Department of Environmental Sciences, University of California Riverside, Riverside, CA, USA. \\ ${ }^{4}$ Tashkent Institute of Irrigation and Melioration, Tashkent, Uzbekistan. \\ * Corresponding author. E-mail: akmalkarimov040@gmail.com
}

\begin{abstract}
The study examines possible water savings by replacing alfalfa with winter wheat in the Fergana Valley, located upstream of the Syrdarya River in Central Asia. Agricultural reforms since the 1990s have promoted this change in cropping patterns in the Central Asian states to enhance food security and social benefits. The water use of alfalfa, winter wheat/fallow, and winter wheat/green gram (double cropping) systems is compared for high-deficit, low-deficit, and full irrigation scenarios using hydrological modeling with the HYDRUS-1D software package. Modeling results indicate that replacing alfalfa with winter wheat in the Fergana Valley released significant water resources, mainly by reducing productive crop transpiration when abandoning alfalfa in favor of alternative cropping systems. However, the winter wheat/fallow cropping system caused high evaporation losses from fallow land after harvesting of winter wheat. Double cropping (i.e., the cultivation of green gram as a short duration summer crop after winter wheat harvesting) reduced evaporation losses, enhanced crop output and hence food security, while generating water savings that make more water available for other productive uses. Beyond water savings, this paper also discusses the economic and social gains that double cropping produces for the public within a broader developmental context.
\end{abstract}

Keywords: HYDRUS-1D; Food security; Crop evapotranspiration; Water budget; Syrdarya River.

\section{INTRODUCTION}

The population of Central Asia doubled during the last 30 years (from 1980 to 2010), thereby increasing the demand for food crops with corresponding implications for water, land, and ecosystem resources. Since the independence of the Central Asian States in 1991, there have been various agricultural policy reforms that included the abolishment of state-planned crop production as well as the implementation of various policies, such as certain cropping patterns, to increase the operational autonomy of farmers and to achieve a range of economic and national political goals. For instance, as they moved from centrally-planned to market economies after the 1990s, the newly independent states reoriented their national agricultural policies toward "grain independency." Ensuing changes in cropping patterns were also thought to promote rural growth, increase farmers' incomes and national food security, as well as to build community resilience against water scarcity and the rising demand for water to grow more food crops. This was prioritized by the end of the 1990s by shifting from a cotton (6year)/alfalfa (3-year) crop rotation to a cotton (2-year)/winter wheat (2-year) sequence. Various studies showed that such interventions impacted food production and consumption, as well as public welfare (Anderson, 2007) and ecosystem services (Spoor, 1998). The changes in cropping patterns from alfalfa to wheat reduced the irrigation water demand. Reducing water diversions for irrigation in the Fergana Valley also resulted in reduced return flow to the river system. In addition, the competition for water between upstream hydropower and irrigation caused an unpredictable inter-seasonal and long-term variability of Syrdarya River flow rates. The many factors involved made it difficult to precisely evaluate the impact of changes in the cropping pattern on water resources available for downstream users.
Two aspects of the cropping changes require clarification: the magnitude of water savings, and likely socioeconomic gains of the changes to the public. In this paper, water savings are defined as the reallocation of water from a current use that produces low, negligible, or negative benefits, to those that generate higher benefits (Molden, 1997; Seckler 1996). Managing the irrigation demand by reducing the beneficial use in agriculture may not always bring real water savings (Ward and Pulido-Velazquez, 2008). It may result in lowering the productivity of the use of thermal and land resources, affecting instream use values (Ward and Booker, 2003), increasing salinity (Khan and Hanjra, 2008), and negatively impacting ecosystem health (Karimov et al., 2014), but it may also deliver other socioeconomic benefits including incomes, employment, revenue, and gains in food security (Molden et al., 2010) for both rural and urban consumers. This highlights the necessity to quantitatively assess the impact of cropping changes beyond land and water savings and to consider also other social gains to the wider public. This paper thus analyzes the effect of water savings and socioeconomic gains due to the replacement of alfalfa by winter wheat within the context of agricultural policy changes that were implemented since 1992 in the Fergana Valley, upstream of the Syrdarya River basin in Uzbekistan.

Irrigated agriculture ( 0.9 million ha) in the Fergana Valley represents an example of large-scale irrigation in Asia. The valley has enormous potential for food crop production. For instance, the valley receives thermal resources with a capacity to evaporate about $10,000 \mathrm{Mm}^{3} \mathrm{yr}^{-1}$ of water (Karimov et al., 2012). Irrigated crops grown in the valley have the potential to utilize $70-80 \%$ of received solar energy if crop growth is not constrained by water deficits or other agronomic and economic factors. However, actual evapotranspiration is much less and ranges from $5,500-6,500 \mathrm{Mm}^{3} \mathrm{yr}^{-1}$, of which only $70 \%$ is transpired by crops (Karimov et al., 2012). While utilizing only 38- 
$45 \%$ of available energy, farmers of the Fergana Valley produce over 0.85 million tons $(\mathrm{Mt})$ of cotton, $1.3 \mathrm{Mt}$ of wheat, and $1 \mathrm{Mt}$ of vegetables and other agricultural commodities. Current production could be increased twofold if thermal, land, and water resources are used in the most productive way. In order to achieve this, it is important to reallocate water from uses that produce low or no benefits to those that generate higher benefits (Molden, 1997; Molden and Sakthivadivel, 1999), and thus improve water productivity, achieve more welfare per drop of water (Giordano et al., 2017; Molden et al., 2010), and contribute towards building community resilience and enhancing water, food, and energy security (Hanjra and Qureshi, 2010; Jalilov et al., 2013; Karimov et al., 2017).

A centerpiece of the applied agricultural policies was the replacement of cotton/alfalfa crop rotation, which dominated in the Fergana Valley in the past, with a cotton/wheat sequence that should increase grain production and reduce cotton-grown areas by allocating these lands to vegetables. Unfortunately, additional opportunities for crop intensification through double cropping, such as growing green gram or other food legume crops on the fallow land after harvesting winter wheat, did not receive state policy support.

Green gram (Vigna radiata L.) is an important food legume in some parts of Central Asia, including the densely populated Fergana Valley and the Tashkent region. Adoption of green gram may offer important welfare benefits to rural areas (Mavlyanova and Sharma, 2015; Verkaart et al., 2017). The green gram cropping season is short and ranges from 90-120 days, depending on the variety (Mavlyanova and Sharma, 2015). Since the harvesting season of winter wheat in the study area ends by June 20 and the next sowing season starts on October 1, short-duration varieties of green gram can be grown between these dates during the summer season. However, due to shortage of water for irrigation of cotton from June to $\mathrm{Au}-$ gust, policy makers restricted double cropping during the summer season to "save" water for irrigation of cotton. As a consequence, green gram prices in local markets have risen, in some years reaching \$1-2 per kg (U.S. Dollars). Gram is also a very nutritious source of protein for human consumption and a key ingredient of animal feed. It is a leguminous crop that can improve soil carbon and nitrogen fixation, enhance soil fertility (Gan et al., 2010), and reduce costs of nitrogen fertilizers and their negative impacts on waterways and the ecosystem (Evans et al., 2012; Huang et al., 2017). These multitudes of benefits thus motivated our choice of modeling green gram (or other pulse crops/legumes) as a second crop in order to contribute to the discussion on sustainable crop intensification as well as related policy and institutional support measures in the region.

The shift in cultivation from alfalfa to winter wheat was attractive to policy makers for several reasons, particularly as a measure to achieve grain independency and as a low investment strategy to bring rapid results by decreasing irrigation water demands. However, real water savings due to a decrease in the irrigation water demand were often only assumed rather than empirically demonstrated (Awan et al., 2017; Cai et al., 2002; Nandalal and Hipel, 2007) in a post-policy implementation context and with associated socioeconomic benefits such as gains in national revenue, farmers income, employment, food security, and livelihood. Although further increases in crop output via intensification through double cropping and corresponding social gains are possible through supportive policy changes, they have not been examined in the literature. Therefore, the objectives of this paper were twofold: 1) to estimate water savings and socioeconomic gains from the replacement of alfalfa with winter wheat, and 2) to test double cropping as a strategy for increasing water savings and socioeconomic gains due to changes in the cropping pattern through further agricultural reforms.

This study uses the HYDRUS-1D (Šimůnek et al., 2008) software to simulate crop transpiration and evaporation from the alfalfa, winter wheat/fallow and winter wheat/green gram double cropping fields. The central thrust of our analysis is to examine double cropping by using the winter wheat/green gram cropping system as an example, thus contributing to the discussion on further reforms and liberalization of the agricultural policies. We analyzed three alternative irrigation regimes: full irrigation (FI), high-deficit irrigation (HDI), and low-deficit irrigation (LDI), all under deep and shallow water table conditions in the Fergana Valley. Silt loam soils, which dominate in the central part of the valley, were selected for this analysis. The results of this modeling exercise could contribute to the discussion on policy options available for enhancing the food security and social gains in other large irrigation systems and river basins that are prone to water scarcity and are facing resilience and sustainability challenges similar to the Fergana Valley.

\section{METHODS AND DATA Study area}

The Fergana Valley is located upstream of the Syrdarya River and is a part of three countries of Central Asia: Kyrgyzstan, Tajikistan, and Uzbekistan. The climate is semi-arid with a low quantity of precipitation and high summer temperatures. Annual precipitation varies from 100 to $250 \mathrm{~mm}$ in the central part of the valley and increases to $300 \mathrm{~mm}$ in the piedmont areas. The mean average temperature is $14^{\circ} \mathrm{C}$, the average minimum temperature $-18^{\circ} \mathrm{C}$, and the average maximum temperature $+45^{\circ} \mathrm{C}$. The altitude increases from west to east from $330 \mathrm{~m}$ above sea level (a.s.l.) to $600 \mathrm{~m}$ a.s.l. The valley is filled with alluvial deposits washed out by multiple rivers in the mountain zone. Rivers in the Fergana Valley are divided into four types according to the source of water: glacier-snow, snow-glacier, snow, and snow-rain (Shultsc, 1949). The glacier and snow-fed river systems have maximum high flows from July through August, the snow and glacier-fed river systems from May through June, the snow-fed river systems from April through May, and the snow and rain-fed river systems in April. Three zones representing hydrogeological conditions of the Fergana Valley are a groundwater natural-recharge zone (Zone A), a groundwater springs zone dominated by upward fluxes (Zone B), and a groundwater discharge zone (Zone $\mathrm{C}$ ), as shown in Fig. 1 (Borisov, 2007; Mirzaev, 1974). These hydrogeological conditions favor the use of fresh groundwater. However, groundwater is used in a few areas only to supplement canal irrigation. As a consequence of underutilization of groundwater, about 200,000 ha of the irrigated land have a relatively shallow water table (less than $2 \mathrm{~m}$ below the soil surface), which causes at times secondary salinization. As a result, over $55 \%$ of irrigated soils are prone to salinity, including 71,922 ha of highly saline lands in the hydrogeological Zone C. A detailed description of soils of the study area is given by Shreder et al., (1977) and Talipov (1992).

Two main time periods can be identified in the recent history of crop cultivation in the Fergana Valley. Until the early 1990s, cotton/alfalfa crop rotation dominated the irrigated lands. Fig. 2 shows that in 1992, the areas under cotton and alfalfa were 39\% and $20 \%$ of the total irrigated area, respectively, while winter wheat was grown only on $8 \%$ of the irrigated area. The irrigation demand of the Fergana Valley at the time was about 


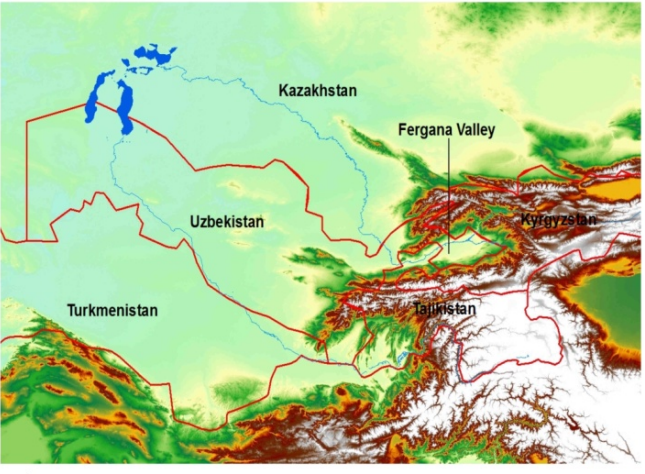

a)

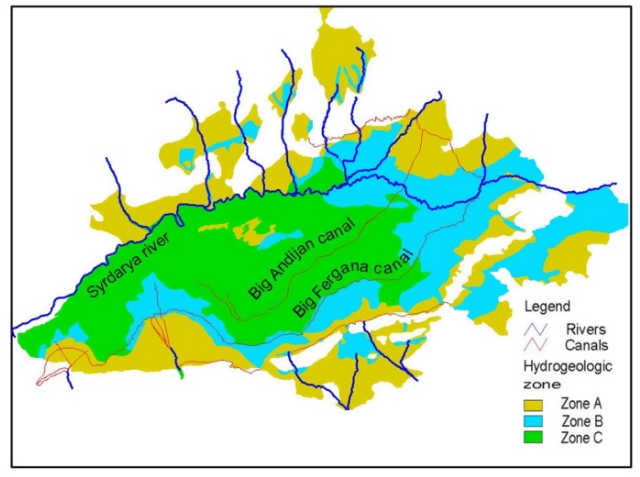

b)

Fig. 1. (a) The Aral Sea basin and (b) hydrogeological zones of the Fergana Valley.

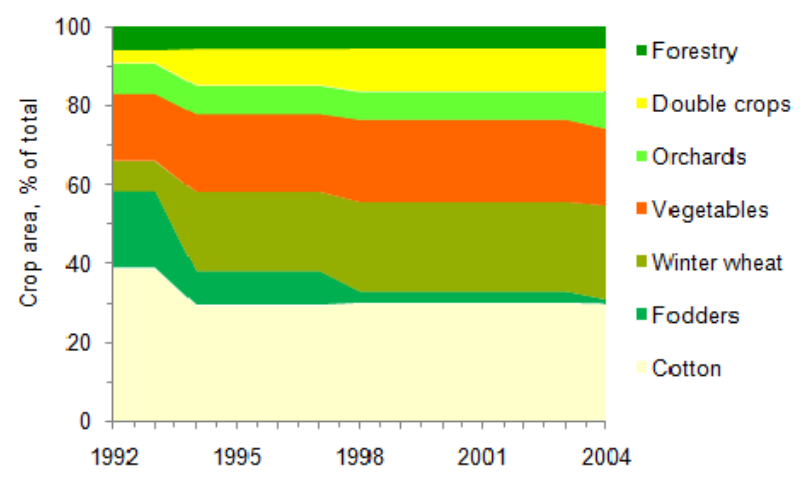

Fig. 2. Changes in the cropping patterns in the Fergana Valley.

$12,000 \mathrm{Mm}^{3} \mathrm{yr}^{-1}$, with plentiful water available for crop production. As the Central Asian States moved from centrally planned to market economies, various agricultural reforms, including changes in cropping patterns, were implemented. After 1995, the dominant cotton/alfalfa crop rotation in the region was replaced by a cotton/wheat sequence due to the national policy of increasing grain production and enhancing food security. The area under irrigated winter wheat was increased to $27 \%$, while the area under alfalfa was reduced to just $1 \%$ of the total irrigated area. Also, the cotton-grown area was reduced by another 47,348 ha, mostly replaced by the cultivation of vegetables. Currently, two main crops, cotton and winter wheat, occupy about $54 \%$ of the irrigated lands of 900,000 ha. Farmers sow winter wheat in early October and harvest it in June, and sow cotton in April and harvest it in September-October. As a result of the cropping changes, the irrigation demand in the Fergana Valley was reduced by about $800 \mathrm{Mm}^{3} \mathrm{yr}^{-1}$.

The changes in the cropping pattern had two main national policy goals: (1) to increase the production of grain crops and therefore to gain independency and national food security, and (2) to reduce the consumption of water per unit of crop production (i.e., to increase water productivity and address water scarcity). The first objective was easily achieved thanks to the expansion of the area allocated to winter wheat, coupled with an increase in average wheat yield from 2 to 5 t/ha. The achievement of the second objective (i.e., increasing water productivity) was not straightforward due to the wide extent of shallow groundwater, which resulted in upward fluxes into the crop root zone, and consequently non-consumptive evapotranspiration and water losses from fallow land after winter wheat harvesting. Sustainable management of the shallow water table and cropping changes are thus key to improving water productivity and food security.

\section{HYDRUS-1D simulations}

The HYDRUS-1D software package (Šimůnek et al., 2008; 2016) was used to estimate crop transpiration and soil evaporation, as well as to examine the effects of policy/crop changes on potential water savings. HYDRUS-1D is a finite-element numerical model that simulates the one-dimensional movement of water, heat and multiple solutes in variably-saturated porous media. The model has been previously used and verified in a number of studies modeling the contribution of shallow groundwater to root water uptake and crop evapotranspiration (e.g., Forkutsa et al., 2009; He et al., 2017; Hernandez, 2001; Li et al., 2015; Sanchez et al., 2003; Shouse et al., 2011; Soylu et al., 2011). For instance, Forkutsa et al. (2009) simulated soil water dynamics and transport of salts in plots with irrigated cotton influenced by a shallow groundwater, while Shouse et al. (2011) analyzed root water uptake from a shallow saline groundwater. Li et al. (2015) similarly studied the dynamics of soil water, soil salinity, and depths to the groundwater table as affected by root water uptake of Chinese tamarisk. He et al. (2017) further used HYDRUS-1D to simulate the irrigated winter wheat/summer maize rotation system in the North China Plain for a total of 15 years. One of the advantages of the model for our study is that it provides estimates of upward fluxes from a shallow groundwater table during deficit irrigation (e.g., Karimov et al., 2014).

The HYDRUS-1D model simulates variably-saturated water flow by solving the Richards equation written as:

$$
\frac{\partial \theta}{\partial t}=\frac{\partial}{\partial z} K\left(\frac{\partial h}{\partial z}+1\right)-S
$$

where $\theta$ is the volumetric water content $\left(\mathrm{cm}^{3} / \mathrm{cm}^{3}\right), t$ represents time (day), $z$ is the vertical coordinate (positive upward) $(\mathrm{cm}), h$ denotes the pressure head $(\mathrm{cm}), K$ is the unsaturated hydraulic conductivity (cm/day), and $S$ is the soil water extraction rate by plant roots $\left(\mathrm{cm}^{3} / \mathrm{cm}^{3} /\right.$ day).

HYDRUS-1D used the Penman-Monteith equation (Allen et al., 1998) to estimate evapotranspiration rates. We used the model to first estimate evapotranspiration, soil evaporation, and crop transpiration for alternative cropping systems for different irrigation scenarios. Then, based on the results of these simulations, we compared water savings, crop yield, and water productivity of alternative cropping systems. The following indicators were evaluated for each cropping pattern: water resources available for reallocation $(W R)$, water savings $(W S)$, and changes in productive water use $(P W)$, all given in $\mathrm{mm}$ over the cropping season. Water resources available for reallocation, $W R_{a}$, were estimated as follows: 
$W R_{a}=E T_{a . a}-E T_{a . w}$

where $E T_{a . a}$ is the estimated actual evapotranspiration from the alfalfa field, and $E T_{a . w}$ the estimated actual evapotranspiration for the alternative cropping system.

Water savings, WS, were estimated as follows:

$$
\begin{aligned}
& W S_{a . w f}=E_{a}-E_{w f} \\
& W S_{a . w g}=E_{a}-E_{w g}
\end{aligned}
$$

where $W S_{a . w f}$ are water savings obtained by replacing alfalfa with the winter wheat/fallow system, $W S_{\text {a.wg }}$ are water savings obtained by replacing alfalfa with winter wheat/green gram double cropping, $E_{a}$ is soil evaporation from the alfalfa field, $E_{w f}$ is soil evaporation from the winter wheat/fallow field, and $E_{w g}$ is soil evaporation from the winter wheat/green gram double cropping field.

Water resources, gained by shifting from alfalfa to alternative cropping systems, represent a sum of changes in non-productive evaporation and productive crop transpiration. Water savings account for only a fraction of released water resources (i.e., non-productive evaporation) and ignore the reduction in productive water use. Changes in productive water use were estimated as the difference in transpiration between alfalfa and the alternative crop fields:

$$
\begin{gathered}
P W_{a . w f}=T_{a}-T_{w f}, \\
P W_{\text {a.wg }}=T_{a}-T_{w g},
\end{gathered}
$$

where $P W_{a . w f}$ and $P W_{a . w g}$ are the productive water reductions as a result of replacing alfalfa with the winter wheat/fallow and winter wheat/green gram double cropping systems, respectively, while $T_{a}, T_{w f}$ and $T_{w g}$ represent crop transpiration from the alfalfa, winter wheat/fallow and winter wheat/green gram cropping systems, respectively.

The yield of alternative cropping systems was estimated using FAO's expression for the yield response to ET (Doorenbos and Kassam, 1979):

$$
\left(1-\frac{Y_{a}}{Y_{x}}\right)=k_{y}\left(1-\frac{E T_{a}}{E T_{x}}\right)
$$

where $Y_{x}$ and $Y_{a}$ are the maximum and actual yields $(\mathrm{kg} / \mathrm{ha})$, respectively, $E T_{x}$ and $E T_{a}$ are crop evapotranspiration for no water stress conditions and actual evapotranspiration $(\mathrm{mm})$, respectively, and $k_{y}$ is a yield response factor representing the effect of a reduction in evapotranspiration on yield losses. For winter wheat/green gram double cropping, the wheat equivalent yield of green gram was calculated on the basis of average prices of green gram and wheat grain. The yield response factor was adopted as follows: 1.1 for alfalfa, 1.0 for winter wheat, and 1.15 for green gram (Doorenbos and Kassam, 1979). The water productivity $(W P)$ was then calculated using the following relationship:

$$
W P=\frac{Y_{a}}{E T_{a}}
$$

The revenue from the cultivation of alfalfa was computed by multiplying the average local price with the yield of alfalfa hay, while the same was done for wheat/green gram. The economic water productivity of alfalfa was calculated by multiplying the water productivity with the average local price of alfalfa hay, with again the same procedure applied to wheat/green gram.

\section{HYDRUS-1D input parameters}

The soil profile was assumed to be $300 \mathrm{~cm}$ deep. Soil textures and soil bulk densities were determined on soil samples collected in 2006 from a field in the Kuva district at soil depths of $0-30,30-60,60-90,90-120,120-180$, and $180-300 \mathrm{~cm}$. Soil water contents were determined before sowing of winter wheat in the same soil profile. The soil texture throughout the entire soil profile was found to be silt loam according to the USDA classification. For the purpose of numerical modeling, the soil profile was divided into six soil horizons that were characterized by four soil materials, determined based on the soil description.

The van Genuchten-Mualem model (van Genuchten, 1980) was selected for the soil water retention curves and unsaturated hydraulic conductivity functions. Simulations were run without considering hysteresis. Initial values of the van GenuchtenMualem parameters of each soil layer were taken from the HYDRUS-1D database for silt loam. These parameters were then calibrated using an inverse analysis of data from the lysimeter study carried out earlier in the same area by Ganiev (1979). The lysimeters, having a $1.44 \mathrm{~m}^{2}$ surface area, were packed with a monolithic silt loam soil, and sown with cotton. The groundwater table in the lysimeters was kept at constant depths of $1.5,2,2.5$, and $3 \mathrm{~m}$ below the soil surface. Soil water contents before the growing season, along with the climate and cotton phenology parameters, were used as input to the model. Daily estimates of upward fluxes from the groundwater table and soil water contents during the growing season, found in the lysimeter study, were used to define the objective function for the inverse analysis. The inverse simulation period spanned 365 days and the model calibration consisted of several steps. First, the van Genuchten-Mualem parameters of the two upper soil layers were optimized while they were kept constant for the two lower soil layers. Then, parameters of the upper two soil layers were updated and kept constant, while they were optimized for the lower two soil layers. This procedure was repeated several times until differences between measured and simulated values stopped decreasing. The final root mean square errors (RMSE) and the relative mean absolute errors (RMAE) between measured and simulated values were relatively low and equal to $0.0199 \mathrm{~cm}$ and $1.48 \%$, respectively. The correlation coefficient between simulated and measured values $(r)$ was 0.927 . The final inversely estimated van Genuchten-Mualem parameter values of each soil layer are presented in Table 1, in which $\theta_{\text {res }}$ is the residual water content, $\theta_{\text {sat }}$ is the saturated soil water content, $a$ and $n$ are shape parameters, $K_{s}$ is the saturated hydraulic conductivity, and $l$ is the pore-connectivity parameter.

The upper boundary condition was defined using the atmospheric boundary condition at the soil surface in terms of observed daily precipitation (Fig. 3) and calculated potential evapotranspiration rates, the later depending upon the selected cropping system. The lower boundary condition consisted of time-variable daily pressure head values representing the position of the groundwater table. Root water uptake was simulated using the approach of Feddes et al. (1978), with water stress parameters for the crops (Table 2) taken from the HYDRUS-1D database (Taylor and Ashcroft, 1972; Wesseling et al., 1991). Our analysis did not consider the effects of solute stress on root water uptake. While dissolved solids in groundwater within the irrigated zone were about $3000 \mathrm{mg} / \mathrm{l}$, and some salt accumulation 
Table 1. van Genuchten-Mualem parameters for soil hydraulic properties.

\begin{tabular}{lcccc}
\hline Soil layer, cm & $0-60$ & $60-120$ & $120-180$ & $180-300$ \\
\hline Soil type/Parameters & Silt loam & Silt loam & Silt loam & Silt loam \\
$\theta_{\text {res }}\left[\mathrm{cm}^{3} / \mathrm{cm}^{3}\right]$ & 0.038 & 0.0010 & 0.0012 & 0.0010 \\
$\theta_{\text {sat }}\left[\mathrm{cm}^{3} / \mathrm{cm}^{3}\right]$ & 0.407 & 0.250 & 0.301 & 0.336 \\
$\alpha\left[1 / \mathrm{cm}^{3}\right]$ & 0.024 & 0.014 & 0.0016 & 0.0157 \\
$n[-]$ & 1.43 & 5.16 & 1.65 & 1.73 \\
$K_{s}[\mathrm{~cm} / \mathrm{d}]$ & 11.4 & 1.08 & 27.6 & 4.48 \\
$l[-]$ & 0.00055 & 0.054 & 0.0098 & 0.0065 \\
\hline
\end{tabular}

Table 2. Root water uptake: water stress response parameters (Feddes et al., 1978; Šejna et al., 2012) used in the HYDRUS model.

\begin{tabular}{lcccc}
\hline $\begin{array}{l}\text { Root water uptake } \\
\text { parameters }\end{array}$ & Unit & Alfalfa & $\begin{array}{c}\text { Winter } \\
\text { wheat }\end{array}$ & $\begin{array}{c}\text { Green } \\
\text { gram }\end{array}$ \\
\hline PO & {$[\mathrm{cm}]$} & 0 & 0 & -15 \\
POpt & {$[\mathrm{cm}]$} & -1 & -1 & -30 \\
P2H & {$[\mathrm{cm}]$} & -1500 & -500 & -750 \\
P2L & {$[\mathrm{cm}]$} & -1500 & -900 & -2000 \\
P3 & {$[\mathrm{cm}]$} & -16000 & -16000 & -8000 \\
r2H & {$[\mathrm{cm} /$ day $]$} & 0.5 & 0.5 & 0.5 \\
r2L & {$[\mathrm{cm} /$ day $]$} & 0.1 & 0.1 & 0.1 \\
\hline
\end{tabular}

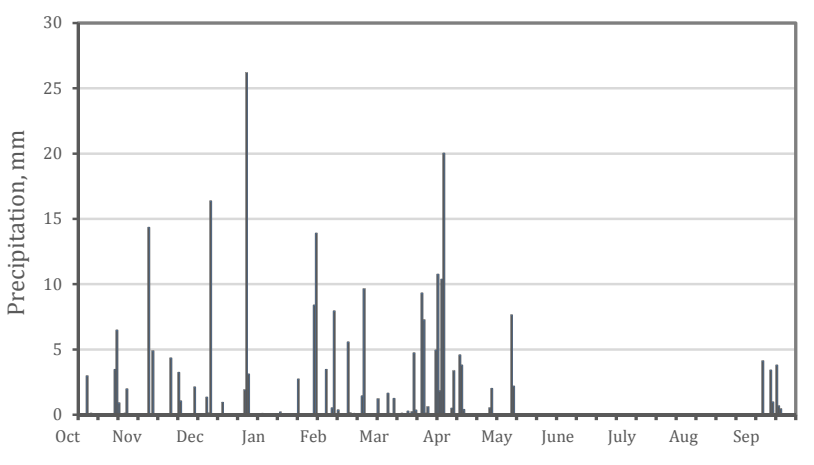

Fig. 3. Precipitation in the Fergana Valley from 1 October, 1994 to 1 October, 1995.

must have occurred in the soil as a result of upward flow from the water table, we decided to focus in our current study only on water stress effects. The effects of salinity stress likely would not change the main conclusions of this study, at least qualitatively, while we recognize that follow-up studies could benefit from a more precise analysis that considers the combined effects of water and salinity stress on root water uptake.

Crop development was accounted for in the model using a daily crop height, a rooting depth, and a soil cover fraction. (Table 3). These parameters, especially the maximum rooting depth, may vary for different scenarios with different irrigation regimes and groundwater depths (Foxx et al., 1982; Grismer,
2015). Unfortunately, little data are available about root development in the presence of shallow groundwater. Considering these limitations, the parameters were selected to be conservative and assumed applicable for the range of conditions simulated by the model.

Climate data, including daily maximum and minimum temperatures, relative humidity, sunshine hours, rainfall, and wind speed, were measured at the Fergana weather station located at a longitude of $71.75^{\circ}$, a latitude of $40.38^{\circ}$, and an elevation of $547 \mathrm{~m}$ a.s.l. Climate data were used from March 1994 to October 1995 with crop growing seasonal totals, representing longterm average. Using these parameters, simulations were carried out for periods of 365 days consistent with the cropping seasons.

\section{Simulated scenarios}

Three following scenarios were analyzed:

Scenario A: Cultivation of alfalfa. Four irrigation regimes were considered: full irrigation (FI) with pre-irrigation soil moisture contents at $70 \%$ of soil field capacity (Shreder et al., 1977); low deficit irrigation (LDI) by reducing irrigations by $25 \%$; high deficit irrigation (HDI) by reducing irrigations by $50 \%$; and rainfed conditions without supplemental irrigation. Four groundwater table depths (of 3, 2.5, 2, and $1.5 \mathrm{~m}$ ) were considered further for each irrigation regime to examine the effects of water table depth on water use of alfalfa. Irrigation applications (including precipitation) were 722-929 $\mathrm{mm}$ under full irrigation, 600-757 mm under LDI, 477-582 mm under HDI, and $232 \mathrm{~mm}$ under rainfed conditions. The selected irrigation rates for shallow groundwater conditions took into consideration upward fluxes as determined in the lysimeter study of Ganiev (1979). Higher irrigation rates were chosen for the deep groundwater conditions having small upward fluxes and lower rates for shallow groundwater conditions with their large upward fluxes. The simulated period for alfalfa was from March 1 to February 28 of the following year.

Scenario B: Winter wheat and land fallowing. After harvesting winter wheat in mid-June, the field was kept fallow until October. The same four irrigation regimes and groundwater table depths as for alfalfa were considered also for winter wheat. Irrigation applications were again reduced for the higher water tables. Irrigation applications were 419-609 mm under FI, 349-524 mm under LDI, 265-434 mm under HDI, and 185 $\mathrm{mm}$ rainfall for rainfed conditions. Simulations for winter wheat covered the period from October 1 to September 30 of the following year. Daily precipitation and potential evaporation rates (the latter when precipitation was zero) were used as an atmospheric boundary condition for land fallowing from June 15 to September 30.

Scenario C: Winter wheat followed by green gram (double cropping). The irrigation regime for winter wheat was the same as for the previous scenario, while for green gram we implemented the irrigation scheme considered by Webber (2008).

Table 3. Main crop parameters for alfalfa, winter wheat, and green gram cultivated in the Fergana Valley*.

\begin{tabular}{lcccc}
\hline Crop parameters & Unit & Alfalfa & Winter wheat & Green gram \\
\hline Crop height, $\max$ & $\mathrm{cm}$ & 68 & 100 & 40 \\
Root depth, $\max$ & $\mathrm{cm}$ & 120 & 100 & 60 \\
LAI/Crop cover, max & & -1.0 & $-/ 0.98$ & $4.2 /-$ \\
Crop vegetation season & & $6 / 03-1 / 11$ & $4 / 10-10 / 06$ & $14 / 06-1 / 10$ \\
Crop harvesting & $\mathrm{t} / \mathrm{ha}$ & $17 / 05 ; 28 / 06 ; 19 / 08 ; 1 / 10$ & $10 / 06$ & $24 / 09-1 / 10$ \\
Yield, max & & 33 & 5.5 & 2 \\
\hline
\end{tabular}

*Data compiled from Edgorov et al. (2006), Sumochkina et al. (1977), Webber (2008), Allen et al. (1998, 2005), Smeal et al. (1991), and Sommer et al. (2013). 
Total irrigation applications for the winter wheat/green gram system were $652-847 \mathrm{~mm}$ under FI, 587-762 $\mathrm{mm}$ under LDI, 503-672 mm under HDI, and $423 \mathrm{~mm}$ for rainfed winter wheat followed by the irrigated green gram. Higher irrigation rates were used again for deep groundwater conditions with low values of upward fluxes and lower rates for shallow groundwater conditions with their higher upward fluxes. The calculated period for the winter wheat/green gram system was from October 1 to September 30 of the following calendar year.

The FAO Excel sheet (Allen et al., 1998) was used for specifying irrigation schedules, dates, and application rates for each crop and simulated groundwater depth using values of the upward fluxes obtained from the lysimeter study discussed above (Ganiev, 1979). Upward fluxes in the lysimeter studies were available only for rainfed conditions. HYDRUS-1D hence used daily irrigation rates from the FAO Excel sheet as input, and then estimated upward fluxes, crop transpiration and evaporation for each irrigation regime and groundwater depth. This is a more accurate approach than the FAO approach since the HYDRUS-1D simulations consider soil texture and soil moisture changes with depth.

The simulation period was the same for all scenarios, i.e., 365 days. However, wheat is sown in the region at the beginning of October and harvested in mid-June, while alfalfa is sown at the beginning of March. We thus followed local farming practices in the region. Values of total irrigation, taken for conditions with a deep groundwater level, were reduced for shallower groundwater tables following locally adopted recommendations. Farmers often irrigate crops based on water availability, which may deviate from crop irrigation requirements (Reddy et al., 2012) and indicate the need for revising current irrigation scheduling practices.

Within the context of policy/crop changes, the following scenarios were conceptualized:

- Scenario A represents policy conditions before the mid 1990s when alfalfa was cultivated in rotation with cotton.

- Scenario B represents policy conditions after the 1990s when winter wheat replaced alfalfa and double cropping was restricted by the policy to "save" irrigation water for the cultivation of cotton.

- Scenario C analyzes the potential future water use of a double cropping system, i.e., a policy option currently under consideration, but still inactive in the region.

\section{RESULTS AND DISCUSSION}

We modeled three cropping scenarios, three alternative irrigation water management regimes and rainfed cropping conditions, and four positions of the groundwater table, as outlined above. Our goal was to evaluate the impact of different cropping scenarios on irrigation water requirements and water use in order to identify the pathways and policy options for improving water productivity and enhancing food security. The results for various cropping scenarios are discussed below.

\section{Water resources available for reallocation}

Estimates of actual evapotranspiration $\left(E T_{a}\right)$ as affected by the alternative cropping systems are given in Table 4 . The estimates for alfalfa show that actual evapotranspiration $\left(E T_{a, a}\right)$ is in the range of 792-905 mm under FI, 760-880 mm under LDI, 690-837 mm under HDI, and 444-654 $\mathrm{mm}$ for rainfed conditions. Higher values of $E T_{a, a}$ were obtained for shallow water table conditions and lower values for deep water table conditions (Scenario A). Under shallow groundwater conditions, crop roots are expected to obtain more water due to capillary rise. This is supported by, among others, a lysimeter study by Soppe and Ayars (2002) who found that a small portion of the root zone of safflower closest to the water table extracted a significant amount of groundwater. Higher soil moisture contents in the crop root zone under shallow water table conditions, as compared to deep groundwater conditions, lead hence to higher transpiration and evapotranspiration rates, especially for alfalfa with their deep dense rooting system.

For the winter wheat/fallow system, differences in crop $E T_{a, w f}$ for different groundwater depths were less obvious under full irrigation, but increased with more deficit irrigation. Changes in $E T_{a}$ were the result of increasing evaporation from the fallowed land after winter wheat harvesting. From June 15 through September 30, higher evaporation losses were estimated under shallow groundwater conditions than for deep water tables. Liu and Luo (2011) similarly found that $E T_{a}$ of winter wheat declined with a lowering of the water table. Differences in $E T_{a}$ for different water table depths were due to the contributions of groundwater to evapotranspiration.

Overall, the shift from alfalfa to the winter wheat/fallow system (Scenario B) reduced $E T_{a}$ by $216-283 \mathrm{~mm}$ under FI, by

Table 4. Released water resources available for reallocation.

\begin{tabular}{|c|c|c|c|c|c|c|}
\hline Scenario & $\begin{array}{c}G W L^{1} \\
\mathrm{~m}\end{array}$ & $\begin{array}{c}E T_{a, a}{ }^{2} \\
\mathrm{~mm}\end{array}$ & $\begin{array}{c}E T_{a, w f}{ }^{3} \\
\mathrm{~mm}\end{array}$ & $\begin{array}{c}E T_{a, w g}{ }^{4} \\
\mathrm{~mm}\end{array}$ & $\begin{array}{c}W A_{a, w f} \\
\mathrm{Mm}\end{array}$ & $\begin{array}{c}W A_{\text {a.wg }}{ }^{6} \\
\mathrm{~mm}\end{array}$ \\
\hline \multirow[t]{4}{*}{ Full irrigation } & 3 & 792 & 576 & 647 & 216 & 145 \\
\hline & 2.5 & 787 & 592 & 668 & 195 & 119 \\
\hline & 2 & 888 & 592 & 674 & 297 & 214 \\
\hline & 1.5 & 905 & 622 & 705 & 283 & 200 \\
\hline \multirow{4}{*}{ Low deficit irrigation } & 3 & 760 & 529 & 618 & 231 & 142 \\
\hline & 2.5 & 760 & 551 & 636 & 209 & 124 \\
\hline & 2 & 855 & 558 & 647 & 297 & 208 \\
\hline & 1.5 & 880 & 624 & 714 & 256 & 166 \\
\hline \multirow[t]{4}{*}{ High deficit irrigation } & 3 & 690 & 496 & 599 & 194 & 91 \\
\hline & 2.5 & 708 & 530 & 633 & 178 & 75 \\
\hline & 2 & 797 & 547 & 642 & 250 & 155 \\
\hline & 1.5 & 837 & 599 & 697 & 238 & 140 \\
\hline \multirow[t]{4}{*}{ Rainfed } & 3 & 444 & 371 & 475 & 73 & -31 \\
\hline & 2.5 & 515 & 437 & 540 & 78 & -25 \\
\hline & 2 & 572 & 496 & 600 & 76 & -28 \\
\hline & 1.5 & 654 & 601 & 700 & 53 & -46 \\
\hline
\end{tabular}

${ }^{1}$ Groundwater table depth, ${ }^{2}$ actual evapotranspiration from the alfalfa field, ${ }^{3}$ actual evapotranspiration from the winter wheat/fallow field, ${ }^{4}$ actual evapotranspiration from the winter wheat/green gram double cropping field, ${ }^{5}$ water resources released by shifting from alfalfa to the winter wheat/fallow system, ${ }^{6}$ water resources released by shifting from alfalfa to the winter wheat/green gram double cropping. 
Table 5. Water savings and changes in productive water use achieved by replacing alfalfa with the winter wheat/fallow system or the winter wheat/green gram double cropping.

\begin{tabular}{|c|c|c|c|c|c|c|c|}
\hline Scenario & $\begin{array}{c}G W L^{1} \\
\mathrm{~m}\end{array}$ & $\begin{array}{c}E_{a}^{2} \\
\mathrm{~mm}\end{array}$ & $\begin{array}{c}W S_{a, w f}{ }^{3} \\
\mathrm{~mm}\end{array}$ & $\begin{array}{c}W S_{a, w g}{ }^{4} \\
\mathrm{~mm}\end{array}$ & $\begin{array}{c}T_{a}^{5} \\
\mathrm{~mm}\end{array}$ & $\begin{array}{c}P W_{\text {a.wf }}{ }^{6} \\
\mathrm{~mm}\end{array}$ & $\begin{array}{c}P W_{\text {a.wg }}{ }^{7} \\
\mathrm{~mm}\end{array}$ \\
\hline \multirow[t]{4}{*}{ Full irrigation } & 3 & 341 & 101 & 120 & 451 & 116 & 25 \\
\hline & 2.5 & 338 & 85 & 116 & 449 & 110 & 2 \\
\hline & 2 & 258 & 0 & 50 & 630 & 297 & 164 \\
\hline & 1.5 & 253 & -30 & 59 & 652 & 313 & 141 \\
\hline \multirow[t]{4}{*}{ Low deficit irrigation } & 3 & 327 & 130 & 131 & 433 & 100 & 10 \\
\hline & 2.5 & 319 & 86 & 108 & 441 & 123 & 16 \\
\hline & 2 & 248 & 14 & 57 & 607 & 283 & 150 \\
\hline & 1.5 & 246 & -40 & 43 & 634 & 295 & 123 \\
\hline \multirow[t]{4}{*}{ High deficit irrigation } & 3 & 304 & 116 & 100 & 386 & 78 & -10 \\
\hline & 2.5 & 297 & 82 & 86 & 411 & 96 & -11 \\
\hline & 2 & 231 & 2 & 40 & 566 & 248 & 115 \\
\hline & 1.5 & 226 & -60 & 14 & 611 & 298 & 126 \\
\hline \multirow[t]{4}{*}{ Rainfed } & 3 & 195 & 27 & 10 & 249 & 46 & -41 \\
\hline & 2.5 & 206 & 13 & 17 & 309 & 66 & -41 \\
\hline & 2 & 223 & 4 & 32 & 349 & 72 & -60 \\
\hline & 1.5 & 235 & -53 & 20 & 419 & 106 & -66 \\
\hline
\end{tabular}

${ }^{1}$ Groundwater table depth, ${ }^{2}$ evaporation from the alfalfa field, ${ }^{3}$ water savings achieved by replacing alfalfa with the winter wheat/fallow system, ${ }^{4}$ water saving achieved by replacing alfalfa with winter wheat/green gram double cropping, ${ }^{5}$ crop transpiration from the alfalfa field, ${ }^{6}$ productive water use change after replacing alfalfa with the winter wheat/fallow system, ${ }^{7}$ productive water use change after replacing alfalfa with winter wheat/green gram double cropping.

231-256 mm under LDI, by 192-235 mm under HDI, and 53$73 \mathrm{~mm}$ under rainfed conditions. Higher reductions in $E T_{a}$ were estimated again for shallow groundwater conditions. Total water resources released in the Fergana Valley by shifting from alfalfa to winter wheat/fallow were estimated at 468, 470, 396, and 132 million $\mathrm{m}^{3} / \mathrm{yr}$ for FI, LDI, HDI, and rainfed conditions, respectively, with the released amounts then becoming available for instream and downstream users.

For winter wheat/green gram double cropping, crop $E T_{\text {a.wg }}$ gradually increased with an increase in the water table depth from $3 \mathrm{~m}$ to $1.5 \mathrm{~m}$ below the soil surface and gradually decreased with an increase in the irrigation water deficit. As compared to winter wheat/fallow system, these $E T_{a}$ changes were associated mainly with an increase in crop transpiration. Overall, the shift from alfalfa to winter wheat/green gram double cropping (Scenario C) reduced $E T_{a}$ by $119-214 \mathrm{~mm}$ under FI, by $124-208 \mathrm{~mm}$ under LDI, and by $75-155 \mathrm{~mm}$ under HDI. More substantial reductions in $E T_{a}$ were obtained again for shallow water table conditions. $E T_{a}$ was found to increase by $25-46 \mathrm{~mm}$ under rainfed conditions. Total water resources of the Fergana Valley, which can be released by shifting from alfalfa to winter wheat/green gram double cropping, were estimated at 320,302, and 218 million $\mathrm{m}^{3} / \mathrm{yr}$ for FI, LDI, and HDI regimes. Reducing both evaporation losses $(E)$ and crop transpiration under the studied irrigation regimes releases water resources for other uses. No water was available for reallocation under rainfed conditions.

\section{Water savings}

Estimates of changes in non-productive evaporation $(E)$ as affected by the alternative cropping systems are given in Table 5. The estimates for alfalfa show that non-productive evaporation is $253-341 \mathrm{~mm}$ under full irrigation, 246-327 mm under LDI, 226-304 mm under HDI, and 235-195 mm under rainfed conditions. Higher irrigation applications for deep groundwater conditions resulted in higher water contents in the topsoil and higher evaporation losses. Lower irrigation applications for shallow groundwater conditions and a higher crop soil cover produced lower values of $E$ for all irrigation conditions.
The shift from alfalfa to winter wheat/fallow for deep groundwater table conditions (2.5-3 m below the soil surface) reduced $E$ by $85-101 \mathrm{~mm}$ under FI, by $89-130 \mathrm{~mm}$ under LDI, by $77-114 \mathrm{~mm}$ under HDI, and by $13-27 \mathrm{~mm}$ under rainfed conditions. There were no significant water savings under shallow groundwater table conditions for the considered irrigation options. Under shallow groundwater conditions, evaporation losses had the same magnitudes for the alfalfa field and winter wheat/fallow systems. In the case of alfalfa, evaporation losses occurred mainly during the irrigations, and in the case of the winter wheat/fallow system when the land was fallowed. Total water savings due to shifting from alfalfa to the winter wheat/fallow system in the Fergana Valley were estimated at 74, 90, and 66 million $\mathrm{m}^{3} / \mathrm{yr}$ for FI, LDI, and HDI scenarios, respectively, which is enough for irrigation of 8,000-10,000 ha of the irrigated land. These water savings comprise a minor part of water resources available for reallocation, while a major part is associated with reductions in productive water use (i.e., crop transpiration).

The shift from alfalfa to the winter wheat/green gram double cropping for deep groundwater table conditions (2.5-3 m below the soil surface) reduced $E$ by $116-120 \mathrm{~mm}$ under FI, by $108-$ $131 \mathrm{~mm}$ under LDI, by $86-100 \mathrm{~mm}$ under HDI, and by $10-17$ $\mathrm{mm}$ under rainfed conditions, respectively. There were less significant water savings under shallow groundwater table conditions for all considered irrigation regimes. Total water savings due to shifting from alfalfa to winter wheat/green gram double cropping in the Fergana Valley were estimated at 163, 160,114 , and 38 million $\mathrm{m}^{3} / \mathrm{yr}$ for the FI, LDI, HDI and rainfed regimes, respectively. These water savings are enough for crop production on 14,000-20,000 ha of irrigated land. The estimates indicate that water savings with wheat/green gram double cropping are higher than for the winter wheat/fallow system for all irrigation scenarios. Water savings with winter wheat/green gram double cropping make up most of the water resources available for reallocation as compared to the winter wheat/fallow system, where water available for reallocation originates mainly from reductions in productive water use. 


\section{Productive water use}

Estimates of changes in productive water use $(P W)$ as affected by alternative cropping systems are given in Table 5 . The estimates for alfalfa show that productive transpiration was 451-652 $\mathrm{mm}$ for FI, 433-634 $\mathrm{mm}$ for LDI, 386-611 $\mathrm{mm}$ for HDI, and 249-419 $\mathrm{mm}$ for the rainfed conditions. Higher values of $T_{c}$ were obtained for shallow groundwater tables as compared to deep groundwater conditions. Modeling results indicate that the shift from alfalfa to the winter wheat/fallow system causes a significant decrease in crop transpiration for all irrigation regimes, irrespective of the water table location. Crop transpiration was reduced by $110-313 \mathrm{~mm}$ for FI, $100-295 \mathrm{~mm}$ for LDI, 78-298 $\mathrm{mm}$ for HDI, and 46-106 $\mathrm{mm}$ for the rainfed system, respectively, indicating ineffective water use. Higher reductions in $T_{c}$ were estimated for shallow groundwater conditions as compared to deeper water tables. Total reductions in productive water use, as a result of the shifts from alfalfa to the winter wheat/fallow system, were estimated to be $395,379,340$ and 139 million $\mathrm{m}^{3} / \mathrm{yr}$ for FI, LDI, HDI, and the rainfed conditions, respectively.

The shift from alfalfa to the winter wheat/green gram double cropping reduced productive water use by $141-164 \mathrm{~mm}$ for FI, 123-150 mm for LDI, and 115-126 mm for HDI for shallow groundwater conditions. Crop transpiration was reduced by $2-$ $25 \mathrm{~mm}$ for FI and 10-16 mm for LDI, but increased by 10-11 $\mathrm{mm}$ for HDI under deep groundwater conditions. Crop transpiration was increased by 41 and $60-66 \mathrm{~mm}$ under rainfed conditions for shallow and deep groundwater conditions, respectively. Total reductions in productive water use in the Fergana Valley as a result of the shift from alfalfa to winter wheat/green gram double cropping were found to be 156, 141, and 104 million $\mathrm{m}^{3} / \mathrm{yr}$ for the FI, LDI, and HDI scenarios, respectively. There are potential gains in productive water use of 99 million $\mathrm{m}^{3} / \mathrm{yr}$ for the rainfed scenario. Thus, double cropping for all irrigation scenarios promoted more productive water use instead of unproductive losses from fallow lands.

Table 6 compares estimates of water available for reallocation, water savings, and changes in productive water use as a result of shifting from alfalfa to the winter wheat/fallow and winter wheat/green gram double cropping systems. The estimates show that in areas with shallow groundwater, the shift from alfalfa to the winter wheat/fallow system releases water resources mainly by reducing productive water use. In areas with deep groundwater, free water resources become available thanks to both water savings and reductions in productive water use. These findings indicate that the winter wheat/fallow system is not a suitable water saving alternative for alfalfa for areas with shallow and deep groundwater tables. However, the winter wheat/fallow system might be a suitable alternative cropping system for areas with deep groundwater and highdeficit irrigation conditions.

Water resources available for reallocation as a result of shifting from alfalfa to winter wheat/green gram double cropping are smaller as compared to the winter wheat/fallow system. Free water resources originate in areas with deep groundwater mainly as a result of reducing evaporation, and in areas with shallow groundwater mainly as a result of reducing productive transpiration. Our results show that winter wheat/green gram double cropping is a less suitable cropping system compared to alfalfa in areas with shallow groundwater, while it is a suitable alternative to alfalfa for areas with deep groundwater tables subject to full (FI) and low deficit (LDI) irrigations. The winter wheat/fallow system may be a more suitable cropping system for areas having deep groundwater tables and subject to high deficit irrigation (HDI)

\section{Water productivity}

Estimated alfalfa yields (the above ground biomass) was found to be in the range of 28.5 to $33.0 \mathrm{t} / \mathrm{ha}$ for full irrigation, 27.2-32.0 t/ha for LDI, 24.4-30.3 t/ha for HDI, and 7.3-11.5 $\mathrm{t} / \mathrm{ha}$ for rainfed conditions for deep and shallow water table conditions, respectively (Table 7). As expected, higher values of the biomass were obtained for shallow water table conditions. For the winter wheat/fallow system, the yield of winter wheat was in the range of 5.08-5.5 $\mathrm{t} /$ ha for full irrigation, 4.96$5.18 \mathrm{t} / \mathrm{ha}$ for LDI, 4.91-5.13 t/ha for HDI, and 1.81-2.52 t/ha for rainfed conditions. These estimates did not account for the effects of soil and groundwater salinity, which may affect the yield of winter wheat. The yield of the winter wheat/green gram system, in wheat equivalents, was $8.3-10.1 \mathrm{t} /$ ha for full irrigation, 8.0-10.2 $\mathrm{t} / \mathrm{ha}$ for LDI, 7.7-10.0 $\mathrm{t} / \mathrm{ha}$ for HDI, and 3.2-5.0 $\mathrm{t} / \mathrm{ha}$ for rainfed conditions, respectively.

Table 6. Water available for reallocation, water savings, and changes in productive water use after replacing alfalfa by the winter wheat/fallow system or the winter wheat/green gram double cropping.

\begin{tabular}{|c|c|c|c|c|c|c|c|}
\hline Scenario & $\begin{array}{c}G W L^{1} \\
\mathrm{~m}\end{array}$ & $\begin{array}{c}W A_{\text {a.wf }}{ }^{2} \\
\mathrm{~mm}\end{array}$ & $\begin{array}{c}W S_{a . w f^{3}} \\
\mathrm{~mm}\end{array}$ & $\begin{array}{c}P W_{\text {a.wf }}{ }^{4} \\
\mathrm{~mm}\end{array}$ & $\begin{array}{c}W A_{a . w g}{ }^{5} \\
\mathrm{~mm}\end{array}$ & $\begin{array}{c}W S_{a . w g}{ }^{6} \\
\mathrm{~mm}\end{array}$ & $\begin{array}{c}P W_{\text {a.wg }}{ }^{7} \\
\mathrm{~mm}\end{array}$ \\
\hline \multirow[t]{4}{*}{ Full irrigation } & 3 & 216 & 101 & 116 & 145 & 120 & 25 \\
\hline & 2.5 & 195 & 85 & 110 & 119 & 116 & 2 \\
\hline & 2 & 297 & 0 & 297 & 214 & 50 & 164 \\
\hline & 1.5 & 283 & -30 & 313 & 200 & 59 & 141 \\
\hline \multirow[t]{4}{*}{ Low deficit irrigation } & 3 & 231 & 130 & 100 & 142 & 131 & 10 \\
\hline & 2.5 & 209 & 86 & 123 & 124 & 108 & 16 \\
\hline & 2 & 297 & 14 & 283 & 208 & 57 & 150 \\
\hline & 1.5 & 256 & -40 & 295 & 166 & 43 & 123 \\
\hline \multirow[t]{4}{*}{ High deficit irrigation } & 3 & 194 & 116 & 78 & 91 & 100 & -10 \\
\hline & 2.5 & 178 & 82 & 96 & 75 & 86 & -11 \\
\hline & 2 & 250 & 2 & 248 & 155 & 40 & 115 \\
\hline & 1.5 & 238 & -60 & 298 & 140 & 14 & 126 \\
\hline \multirow[t]{4}{*}{ Rainfed } & 3 & 73 & 27 & 46 & -31 & 10 & -41 \\
\hline & 2.5 & 78 & 13 & 66 & -25 & 17 & -41 \\
\hline & 2 & 76 & 4 & 72 & -28 & 32 & -60 \\
\hline & 1.5 & 53 & -53 & 106 & -46 & 20 & -66 \\
\hline
\end{tabular}

${ }^{1}$ Groundwater table depth, ${ }^{2}$ water resources released by shifting from alfalfa to the winter wheat/fallow system, ${ }^{3}$ water savings achieved by replacing alfalfa with the winter wheat/fallow system, ${ }^{4}$ productive water use change after replacing alfalfa with the winter wheat/fallow system, ${ }^{5}$ water resources released by shifting from alfalfa to the winter wheat/green gram double cropping, ${ }^{6}$ water saving achieved by replacing alfalfa with winter wheat/green gram double cropping, and ${ }^{7}$ productive water use change after replacing alfalfa with winter wheat/green gram double cropping. 
Can a change in cropping patterns produce water savings and social gains: A case study from the Fergana Valley, Central Asia

Table 7. Revenue and water productivity for the alfalfa, winter wheat/fallow and winter wheat/green gram double cropping systems.

\begin{tabular}{|c|c|c|c|c|c|c|c|c|c|c|}
\hline \multirow[t]{2}{*}{ Scenario } & \multirow{2}{*}{$\begin{array}{c}\text { Groundwater } \\
\text { depth }\end{array}$} & \multicolumn{3}{|c|}{ Yield } & \multicolumn{3}{|c|}{ Revenue } & \multicolumn{3}{|c|}{ Economic water productivity } \\
\hline & & Alfalfa & $\begin{array}{l}\mathrm{WWF}^{1} \\
\mathrm{~kg} / \mathrm{ha}\end{array}$ & $\mathrm{WWGG}^{2}$ & Alfalfa & $\begin{array}{l}\text { WWF } \\
\$ / \text { ha }\end{array}$ & WWGG & Alfalfa & $\begin{array}{l}\text { WWF } \\
\$ / \mathrm{m}^{3}\end{array}$ & WWGG \\
\hline \multirow[t]{4}{*}{ FI } & 3 & 28.5 & 5.45 & 8.33 & 1838 & 900 & 1375 & 0.23 & 0.16 & 0.21 \\
\hline & 2.5 & 28.3 & 5.50 & 8.78 & 1825 & 908 & 1449 & 0.23 & 0.15 & 0.22 \\
\hline & 2 & 32.3 & 5.25 & 9.18 & 2083 & 866 & 1514 & 0.23 & 0.15 & 0.22 \\
\hline & 1.5 & 33 & 5.08 & 10.08 & 2129 & 838 & 1663 & 0.24 & 0.13 & 0.24 \\
\hline \multirow[t]{4}{*}{ LDI } & 3 & 27.2 & 5.17 & 7.98 & 1754 & 853 & 1317 & 0.23 & 0.16 & 0.21 \\
\hline & 2.5 & 27.2 & 5.15 & 8.41 & 1754 & 850 & 1388 & 0.23 & 0.15 & 0.22 \\
\hline & 2 & 31 & 4.96 & 8.87 & 2000 & 818 & 1464 & 0.23 & 0.15 & 0.23 \\
\hline & 1.5 & 32 & 5.18 & 10.17 & 2064 & 855 & 1678 & 0.23 & 0.14 & 0.23 \\
\hline \multirow[t]{4}{*}{ HDI } & 3 & 24.4 & 5.00 & 7.72 & 1574 & 825 & 1274 & 0.23 & 0.17 & 0.21 \\
\hline & 2.5 & 25.1 & 5.13 & 8.36 & 1619 & 846 & 1379 & 0.23 & 0.16 & 0.22 \\
\hline & 2 & 28.7 & 4.91 & 8.80 & 1851 & 809 & 1453 & 0.23 & 0.15 & 0.23 \\
\hline & 1.5 & 30.3 & 5.01 & 9.96 & 1954 & 826 & 1643 & 0.23 & 0.14 & 0.24 \\
\hline \multirow[t]{4}{*}{$\mathrm{RF}$} & 3 & 7.3 & 1.81 & 3.16 & 471 & 299 & 521 & 0.11 & 0.08 & 0.11 \\
\hline & 2.5 & 8.7 & 2.04 & 3.66 & 561 & 337 & 604 & 0.11 & 0.08 & 0.11 \\
\hline & 2 & 9.8 & 2.22 & 4.16 & 632 & 367 & 687 & 0.11 & 0.07 & 0.11 \\
\hline & 1.5 & 11.5 & 2.52 & 5.00 & 742 & 416 & 824 & 0.11 & 0.07 & 0.12 \\
\hline
\end{tabular}

${ }^{1}$ Winter wheat/fallow system; ${ }^{2}$ winter wheat/green gram double cropping

The cultivation of alfalfa ensures high revenues for farmers, at \$1838-2129/ha under FI, \$1754-2064/ha under LDI, \$15741974/ha under HDI, and \$471-742/ha under rainfed conditions. Lower revenues were obtained for deep groundwater conditions and higher revenues for shallow groundwater conditions. The shift from alfalfa to winter wheat, with an aim toward food independency and social benefits, reduced the revenues of local farmer communities but enhanced food security. For the winter wheat/fallow scenario, revenues of farmers were estimated at \$838-908/ha for FI, \$818-855/ha for LDI, \$809-846/ha for HDI, and \$299-416/ha for rainfed conditions. The cultivation of green gram after winter wheat harvesting significantly adds to the revenues of farmers by generating new income from land and water resources that would otherwise remain underutilized during fallow periods. The revenues were estimated at $\$ 1375-$ 1663/ha for FI, \$1317-1678/ha for LDI, \$1274-1643/ha for HDI, and \$521-824/ha for rainfed conditions.

The economic water productivity for alfalfa is estimated to be $\$ 0.23-0.24 / \mathrm{m}^{3}$ under irrigation and $\$ 0.11 / \mathrm{m}^{3}$ under rainfed conditions. The economic water productivity for the winter wheat/fallow system is appraised at $\$ 0.13-0.16 / \mathrm{m}^{3}, \$ 0.14$ $0.16 / \mathrm{m}^{3}, \$ 0.14-0.17 / \mathrm{m}^{3}$ for FI, LDI, and HDI, respectively, and $\$ 0.07-0.08 / \mathrm{m}^{3}$ for rainfed conditions. The economic water productivity for winter wheat/green gram double cropping is estimated to be $\$ 0.21-0.24 / \mathrm{m}^{3}$ for irrigation and $\$ 0.11-0.12 / \mathrm{m}^{3}$ for rainfed conditions.

It is expected that with adjustments to the area under alfalfa and winter wheat/green gram double cropping, in accordance with the market opportunities and economics that capture relative commodity prices, the yield stability and effects of legume double cropping on subsequent crop performance will bring together higher revenues to farmers cultivating these two alternative crops. This will also improve the economic productivity of winter wheat/green gram double cropping. However, from a broader perspective, public policies should also provide incentives for value chain development and risk management, and for the establishment of multi-commodity farmer groups and related support measures.

\section{SOCIOECONOMIC GAINS FROM CROPPING POLICY CHANGES}

Our HYDRUS-1D modeling results show that Scenario C pertaining to the potential future water use of a double cropping system produces notable water savings by transforming nonproductive evaporation into productive transpiration and enhancing crop water productivity. Indeed, double cropping by growing green gram/food legumes after harvesting winter wheat instead of leaving crop fields fallow, also improves the economic water productivity $\left(\$ / \mathrm{m}^{3}\right)$ and crop revenue $(\$ / \mathrm{ha})$ for all irrigation regimes. The HYDRUS simulations indicate that the more productive water use leads to gains in water productivity and generates new income and higher economic benefits for farmers, thus clearly offering incentives to support double cropping through policy reforms. However, the successful integration of gram/pulse crops into wheat-based systems depends upon economic, social, and policy drivers (Maaz et al., 2017).

Apart from gains in water savings, shifting from alfalfa to winter wheat-green gram double cropping has several socioeconomic benefits and implications, including gains in income, consumption, employment, and rural livelihoods, and contributions to national and regional food security. For example, consider Scenario B that represents the policy conditions after the 1990s when winter wheat replaced alfalfa. While shifting to wheat cultivation by itself did not bring higher income to farmers of the Fergana Valley, there were several socioeconomic benefits for the wider population and the national economy. First, major benefits were associated with an increase in food production and improvements in consumption patterns in the region. Based on data from the food balance sheets of the Food and Agricultural Organization (FAO) of the United Nations, wheat provides about $53 \%$ of the dietary caloric intake in Uzbekistan, and thus is a major source of calorie consumption by the population. In Central Asia, in general, the consumption of wheat-based food is higher compared to other regions of the world. The wheat-equivalent consumption across Central Asian countries ranges from 138 to $174 \mathrm{~kg}$ capita $^{-1}$ year $^{-1}$ as compared to $66 \mathrm{~kg} \mathrm{capita}^{-1}$ year $^{-1}$ for Asian region as a whole (Chabot and Tondel, 2011). The additional 14,000-20,000 ha of irrigated area and the production of winter wheat under Scenario $C$ can make a significant contribution to food security.

Increasing gram/legume production may also contribute to more balanced nutrition of the population in rural and urban areas and thus improve food security and nutrition outcomes (Pingali, 2015; Verkaart et al., 2017). For example, the potential future double cropping green gram option in areas where alfalfa was replaced by winter wheat on 189,000 ha can produce about 250-280 thousand tons of green gram. Although 
data on green gram consumption are lacking, FAO Stat (2017) shows that the annual pulse consumption per capita in Uzbekistan, Tajikistan, and Kyrgyzstan is quite low (less than $3 \mathrm{~kg}$ ), while the pulse consumption is higher in neighboring countries, including Bangladesh $(5.3 \mathrm{~kg})$, China $(9.4 \mathrm{~kg})$, India $(13.6 \mathrm{~kg})$, Pakistan $(6.2 \mathrm{~kg})$, and Sri Lanka $(9.3 \mathrm{~kg})$, which all have unmet local demand for pulses. Using an average annual gross pulse consumption at $10 \mathrm{~kg}$ per capita, this gram production may serve the pulse consumption needs of about 20 million people in these countries, while generating millions of dollars in export earnings.

The consumption norm recommended by the Ministry of Health of Uzbekistan for meat and meat products is around 46.1 $\mathrm{kg}$, whereas the actual meat consumption was about $28.4 \mathrm{~kg}$ per capita per annum in 2009, indicating a deficit in the meat consumption of about $17.7 \mathrm{~kg}$ per capita. Green gram has only a slightly lower protein content $(24 \%)$ than meat $(26 \%)$, which suggests that gram production could supplement the meat consumption deficit for about 10 million people in Uzbekistan. In terms of supplying the daily protein needs solely from nonmeat alternative sources of protein, this gram production may be sufficient to serve the meat/protein needs of about 6 million people. However, since meat is a high quality complete protein, while gram is an incomplete protein, the meat/protein equivalent estimate should be interpreted cautiously. Also, people tend to substitute pulse-based protein with meat as incomes grow (Stokstad et al., 2010). However, green gram can supply vegetable-based protein at a much lower unit cost $(\$ 3.6 / \mathrm{kg}$ protein) than meat-based protein $(\$ 12.4 / \mathrm{kg})$, and is a lean source of protein with a high fiber and nutrient content that offers multiple health benefits.

The higher food production will help stabilize the food supply and market prices to benefit both farmers and consumers. One of the important issues for the wheat supply in Uzbekistan is that trainfed wheat production in neighboring Kazakhstan shows a considerable degree of inter-annual variability. Export of wheat varies from $4 \%$ to $22 \%$ of total wheat available for consumption. In poor wheat-production years, such as in 20082009 during the global food, wheat export from Kazakhstan dropped by $30 \%$ (Chabot and Tondel, 2011). In spite of this, prices remained low in the local market of Uzbekistan, even as prices on the international market increased substantially. Therefore, due to the increased wheat and legume production in the valley, farmers may benefit from the higher output and additional economic activity in rural areas, while consumers benefit from increased food consumption and lower food prices (Hussain et al., 2004). The increased food production makes food available and affordable for millions of consumers, thus improving their dietary intake, nutrition, and cognitive skills, and contributing towards sustainable human development (Conceiçao et al., 2016). There are also wider benefits in irrigation value chains (agro-processing, cereal products, value addition) and markets (domestic, urban, export) since wheat and green gram can economically support nutritional changes since feeding humans on a cereal- and legumes-based diet requires far fewer resources in terms of water, energy, and land, than meat based diets (Hanjra and Qureshi, 2010; Keyzer et al., 2005; Stokstad, 2010).

The second major impact is a gain in employment. Labor requirements for wheat production in the Fergana Valley are high at 24 person-day ha ${ }^{-1}$ as compared to 5 person-day ha ${ }^{-1}$ for alfalfa (World Bank, 2009). Increasing employment is especially important for the region where the rural population comprises $80 \%$ to $90 \%$ of the total, and district-wise out- migration for job opportunities is quite high and ranges from 2.5-4.5\% (World Bank, 2009).

Farmers' incomes can grow by adopting a double cropping system combining winter wheat with gram/legumes and vegetables. Year-round production with a higher cropping intensity and a more diversified cropping pattern helps to attenuate intra-seasonal variability in employment, output, income, and prices while improving livelihoods and reducing the risks that are so pervasive in agriculture. For example, the production of vegetables can provide much higher incomes for farmers as compared to alfalfa, while employment will increase from 5 to 200-286 person-day ha ${ }^{-1}$ (World Bank, 2009), i.e., to an almost full-time and year-round employment. Rough estimates indicate that the production of vegetables after harvesting winter wheat on the entire wheat production area may create full-time employment for 200,000 people in the Fergana Valley. Vegetables have a higher water productivity (Al-Said et al., 2012) and are also an important part of a nutritious and healthy diet and contribute to export earnings; public policies and investments that support double cropping hence offer high social benefits.

The proposed crop and water management practices also enhance the sustainability of irrigation systems and benefit instream and downstream users. Reduced irrigation water diversions from the Syrdarya River and its tributaries in the Fergana Valley will reduce groundwater recharge and gradually lower the groundwater table, thereby reducing the return flow to the river. This may improve the quality of both groundwater and river flow. Lowering the water table often results in gradual reductions in the area of salt-affected soils and enhance the sustainability of irrigated agriculture (Kijne, 2006).

However, the main socioeconomic gains of water savings in the Fergana Valley are expected to be in downstream subregions, such as the Mirzachul and Djizak steppes of the Syrdarya River basin. Irrigation in these semi-desert zones fully relies on water from the river. Between 1990 and 2000, cotton yields in the Mirzachul steppe located on the left bank downstream of the river plummeted by $46 \%$, while some of the land was taken out of production due to irrigation water shortages and increasing salinity (Kushiev et al., 2005). This had a direct impact on agricultural production, with estimated losses of around $\$ 90.4$ million on 555,000 ha (Keith and McKinney, 1997). Cotton yields declined in this area below 2t $\mathrm{ha}^{-1}$ due to a shortage of irrigation water and salinity buildup in the topsoil. A sustainable water supply is a precondition in these areas to arrest soil salinization, which is the main limitation for crop production. Reduced water diversions for irrigation also offer major energy cost savings, for example in lift irrigation schemes (Karimov et al., 2017), with associated reductions in carbon emissions.

In addition to guaranteeing the continued buildup of the national revenue of the newly independent states, the double cropping policy change could be an approach for increasing rural incomes and enhancing food security. The cotton policy changes increased food production. Increasing green gram production in Uzbekistan may also enhance the export of agricultural products to India, Pakistan, and Afghanistan. The implications of increasing wheat and legumes production and policy changes extend hence well beyond irrigated agriculture in the Fergana Valley to countries in the region facing similar water scarcity and agricultural policy reform challenges. Since the benefit accrues to the public at large and even beyond the national boundaries, the incidence analysis of costs and benefits is quite complex, and benefit-sharing models and policy reforms also require further research. 


\section{CONCLUSIONS AND POLICY IMPLICATIONS}

This paper showed that national policy reforms in Uzbekistan since the 1990s led to changes in the cropping pattern that aimed for greater food security, social benefits, and water savings. A case in point was the analysis of replacing alfalfa with a winter wheat/fallow system and then transitioning to wheat-gram double cropping that currently remains inactive in the agricultural policy. Modeling estimates using HYDRUS1D suggest that:

- The shift from alfalfa to the winter wheat/fallow system released about 400-470 million $\mathrm{m}^{3} / \mathrm{yr}$ of water resources in the Fergana Valley for instream and downstream uses. However, these water resources became available mainly as a result of reducing productive crop transpiration. Water savings associated with reductions in nonproduction evaporation from the change in the cropping pattern are estimated to be only about 66-90 million $\mathrm{m}^{3} / \mathrm{yr}$.

- Winter wheat is not a suitable water-saving alternative crop to replace alfalfa under shallow groundwater conditions due to significant upward fluxes from the water table. As a result, total evaporation losses are of the same magnitude for the alfalfa and winter wheat/fallow systems at different levels of deficit irrigation, while productive transpiration is significantly higher for alfalfa as compared to winter wheat. Shifting from alfalfa to winter wheat on 200,000 ha (or $22 \%$ of the irrigated land in the Fergana Valley with a shallow water table) did not produce water savings but enhanced the wheat output and food security. Yet, the current practice of restricting double cropping under shallow groundwater conditions causes additional evaporation losses from land fallowed after winter wheat harvesting. This implies that further policy reforms and liberalizations that incentivize better land and water management practices could produce water savings and socioeconomic gains for the nation.

- Shifting from alfalfa to winter wheat followed by green gram in areas with groundwater deeper than $2 \mathrm{~m}$ below the land surface can reduce evaporation losses without changes in crop productive transpiration. This double cropping in the Fergana Valley can produce water savings of $114-163$ million $\mathrm{m}^{3} / \mathrm{yr}$ compared to alfalfa at different levels of deficit irrigation, and can increase green gram grain production by $250-280$ thousand tons.

- When only the use of water in agriculture is considered, free water resources gained through the change in the cropping pattern can be reallocated within the Fergana Valley, which has a more productive agriculture as compared to downstream systems. Improving the water supply downstream, which faces water shortages, may be possible through a set of water saving technologies which do not affect crop productive transpiration. When other uses, including environmental, industrial, and instream users, are considered, then water released through the change in the cropping pattern can be considered for reallocation within the river system.

To conclude, double cropping with summer green gram represents an advantageous option for crop intensification and widely-shared socioeconomic gains that may justify public policy support. The cultivation of alfalfa in areas with a shallow groundwater table can be continued, or the ground water table can be lowered in areas with winter wheat/green gram, by extracting groundwater for irrigation of the second crop and promoting the conjunctive use of surface water and groundwater.

Acknowledgements. The authors would like to express their thanks to the OPEC Fund for International Development and the CGIAR Research Program on Water, Land and Ecosystems for financing this work and Dr. Ravza Mavlyanova, Regional Coordinator of the World Vegetable Center for Central Asia for promoting the adoption of green gram among farming communities.

\section{REFERENCES}

Allen, R.G., Pereira, L.S., Raes, D., Smith, M., 1998. Crop evapotranspiration. Guidelines for computing crop water requirements. FAO Irrigation and Drainage Paper 56. FAO, Rome, $300 \mathrm{p}$.

Allen, R.G., Pereira, L.S., Smith, M., Raes, D., Wright, J.L., 2005. FAO-56 dual crop coefficient method for estimating evaporation from soil and application extensions. J. Irrig. Drain. Eng., 131, 2-13.

Al-Said, F.A., Ashfaq, M., Al-Barhi, M., Hanjra, M.A., Khan, I. A., 2012. Water productivity of vegetables under modern irrigation methods in Oman. Irrigation and Drainage (ICID Journal), 61, 4, 477-489.

Anderson, K., 2007. Agricultural trade liberalisation and the environment: a global perspective. World Economy, 15, 153-172.

Awan, U.K., Ibrakhimov, M., Benli, B., Lamers, J.P.A., Liaqat, U.W., 2017. A new concept of irrigation response units for effective management of surface and groundwater resources: a case study from the multi-country Fergana Valley, Central Asia. Irrigation Science, 35, 1, 55-68.

Borisov, V.A., 2007. Groundwater Resources and Their Use in Uzbekistan. Fan, Tashkent, Uzbekistan. (In Russian.)

Cai, X., McKinney, D.C., Rosegrant, M.W., 2002. Sustainability analysis for irrigation water management in the Aral Sea region. Agricultural Systems, 76, 1-24.

Chabot, Ph.,Tondel, F., 2011. A regional view of wheat markets and food security in Central Asia with a focus on Afghanistan and Tajikistan. USAID. http://www.fews.net/ docs/Publications/Regional View of Wheat... (Accessed on 25.12.14).

Conceiçao, P., Levine, S., Lipton, M., Warren-Rodríguez, A., 2016. Toward a food secure future: Ensuring food security for sustainable human development in Sub-Saharan Africa. Food Policy, 60, 1-9.

Doorenbos, J., Kassam, A.H., 1979. Yield response to water. FAO Irrigation and Drainage Paper No. 33. FAO, Rome.

Edgorov, D., Ikramova, M., Azimov, S., 2006. Crop rotation and role of alfalfa on salinity control. Bukhara Branch of the Uzbek Research Institute of Cotton Growing. Bukhara. 64 p.

Evans, A.E. V., Hanjra, M.A., Jiang, Y., Qadir, M., Drechsel, P., 2012. Water quality: assessment of the current situation in Asia. International Journal of Water Resources Development, 28, 195-216.

Feddes, R.A., Kowalik, P.J., Zaradny, H., 1978. Simulation of Field Water Use and Crop Yield. John Wiley \& Sons, New York.

Forkutsa, I., Sommer, R., Shirokova, Y.I., Lamers, J.P., Kienzler, K., Tischbein, B., Martius, C., Vlek, P.L.G., 2009. Modeling irrigated cotton with shallow groundwater in the Aral Sea Basin of Uzbekistan: I. Water dynamics. Irrig. Sci., 27, 331-346. DOI: 10.1007/s00271-009-0148-1.

Foxx, T.S., Tierney, G.D., Williams, J.M., 1982. Rooting depths of plants relative to biological and environmental factors. Los Alamos National Laboratory, 28 p. https://www.iaea.prg/inis/collection/NCLCollectionStore/_P ublic/16/061/16061888.pdf. 
Grismer, M.E., 2015. Use of shallow groundwater for crop production. ANR Publication., $6 \quad 6 \quad$ p. http://anrcatalog.ucanr.edu.

Gan, Y.T., Warkentin, T.D., Bing, D.J., Stevenson, F.C., McDonald, C.L., 2010. Chickpea water use efficiency in relation to cropping system, cultivar, soil nitrogen and Rhizobial inoculation in semiarid environments. Agricultural Water Management, 97, 1375-1381.

Ganiev, K.G., 1979. Evaporation and Infiltration Recharge of Groundwater. Fan, Tashkent, Uzbekistan (In Russian.)

Giordano, M., Turral, H., Scheierling, S.M., Tréguer, D.O., McCornick, P.G., 2017. Beyond 'More Crop per Drop'. Research Report 169. International Water Management Institute (IWMI), Colombo, Sri Lanka; The World Bank, Washington, DC, USA.

Hanjra, M.A., Qureshi, M.E., 2010. Global water crisis and future food security in an era of climate change. Food Policy 35, 2, 365-377.

He, K., Yang, Y., Yang, Y., Chen, S., Hu, Q., Liu, X., Gao, F., 2017. HYDRUS simulation of sustainable brackish water irrigation in a winter wheat-summer maize rotation system in the North China Plain. Water, 9, 536.

Hernandez, T.X., 2001. Rainfall-runoff modeling in humid shallow water table environments. MSc Thesis. University of South Florida.

Hussain, I., Mudasser, M., Hanjra, M.A., Amrasinghe, U., Molden, D., 2004. Improving wheat productivity in Pakistan: econometric analysis using panel data from Chaj in the upper Indus Basin. Water International, 29, 189-200.

Huang, J., Xu, C., Ridoutt, B.G., Wang, X., Ren, P., 2017. Nitrogen and phosphorus losses and eutrophication potential associated with fertilizer application to cropland in China. Journal of Cleaner Production, 159, 171-179.

Jalilov, S.M., Amer, S.A., Ward, F.A., 2013. Water, food, and energy security: an elusive search for balance in Central Asia. Water Resources Management, 27, 11, 3959-3979.

Karimov, A., Molden, D., Khamzina, T., Platonov, A., Ivanov, Y., 2012. A water accounting procedure to determine the water savings potential of the Fergana Valley. Agricultural Water Management, 108, 61-72.

Karimov, A.K., Šimůnek, J., Hanjra, M.A., Avliyakulov, M., Forkutsa, I., 2014. Effects of the shallow water table on water use of winter wheat and ecosystem health: Implications for unlocking the potential of groundwater in the Fergana Valley (Central Asia). Agricultural Water Management, 131, 0, 57-69.

Karimov, A.K., Smakhtin, V., Karimov, A.A., Khodjiev, Kh., Yakubov, S., Platonov, A., Avliyakulov, M., 2017. Reducing the energy intensity of lift irrigation schemes of Northern Tajikistan- potential options. Renewable and Sustainable Energy Reviews. doi.org/10.1016/j.rser.2017.06.107

Keith, J.E., McKinney, D.C., 1997. Option analysis of the operation of the Toktogul reservoir. Issue Paper No. 7. www.ce.utexas.edu/prof/mckinney/ce397/Topics/Options Toktogul 3.pdf. (Accessed on 20.02.2014).

Keyzer, M.A., Merbis, M.D., Pavel, I.F.P.W., van Wesenbeeck, C.F.A., 2005. Diet shifts towards meat and the effects on cereal use: can we feed the animals in 2030? Ecological Economics, 55, 187-202.

Khan, S., Hanjra, M. A. 2008. Sustainable land and water management policies and practices: A pathway to environmental sustainability in large irrigation systems. Land Degradation and Development, 19, 469-487.
Kijne, J.W., 2006. Salinisation in irrigated agriculture in Pakistan: mistaken predictions. Water Policy, 8, 325-38.

Kushiev, K., Noble, A.D., Abdullaev, I., Toshbekov, U., 2005. Remediation of abandoned saline soils using Glycyrrhiza glabra: A study from the Hungry Steppes of Central Asia. Int. J. Agric. Sustain., 3, 2, 102-113.

Li, H., Yi, J., Zhang, J., Zhao, Y., Si, B., Lee, R., Cui, L., Liu, X., 2015. Modeling of soil water and salt dynamics and its effects on root water uptake in Heihe Arid Wetland, Gansu, China. Water, 7, 2382-2401. DOI: 10.3390/w7052382.

Liu, T., Luo, Y., 2011. Effect of shallow water tables on the water use and yield of winter wheat (Triticum aestivum L.). AJCS, 5, 13, 1692-1697.

Maaz, T., Wulfhorst, J.D., McCracken, V., Kirkegaard, J., Huggins, D.R., Roth, I., Kaur, H., Pan, W., 2017. Economic, policy, and social trends and challenges of introducing oilseed and pulse crops into dryland wheat cropping systems. Agriculture, Ecosystems \& Environment, doi.org/10.1016/j.agee.2017.03.018.

Mavlyanova, R., Sharma, R.C., 2015. High quality seed production of wheat and mungbean in Kuva, Fergana. Report. ICARDA, Tashkent. www.cac-program.org/files/ ec9f7aca08a1460f0debbbab0399c61c.pdf

Mirzaev, S.Sh., 1974. Groundwater Storages of Uzbekistan . Fan, Tashkent, Uzbekistan. (In Russian.)

Molden, D., 1997. Accounting for water use and productivity. SWIM Paper 1. International Water Management Institute, Sri Lanka.

Molden, D., Sakthivadivel, R., 1999. Water accounting to assess use and productivity of water. International Journal of Water Resources Development, 15, 1\&2, 55-71.

Molden, D., Oweis, T., Steduto, P., Bindraban, P., Hanjra, M.A., Kijne, J., 2010. Improving agricultural water productivity: Between optimism. Agric. Water Manage., 97, $4,528-535$.

Nandalal, W., Hipel, W., 2007. Strategic decision support for resolving conflict over water sharing among countries along the Syr Darya River in the Aral Sea Basin. Journal of Water Resources Planning and Management, 133, 289-299.

Pingali, P., 2015. Agricultural policy and nutrition outcomes getting beyond the preoccupation with staple grains. Food Security, 7, 3, 583-591.

Reddy, J.M., Muhammedjanov, Sh., Jumaboev, K., Eshmuratov, D., 2012. Analysis of cotton water productivity in Fergana Valley. Agricultural Science, 3, 6, 822-834.

Sanchez, C.A., Zerihun, N.I., Warrick, A.W., Furman, A., 2003. Efficient surface fertigation of high value horticulture crops. In: Western Nutrient Management Conference, Salt Lake City, UT, pp. 77-82.

Seckler, D., 1996. The New Era of Water Resources Management: From "Dry" To "Wet" Water Savings. Research Report 1. International Irrigation Management Institute (IIMI), Colombo, Sri Lanka.

Šejna, M., Šimůnek, J., van Genuchten, M.Th., 2012. The Hydrus software package for simulating the two- and threedimensional movement of water, heat, and multiple solutes in variably-saturated media. HYDRUS User manual, Version 2. PC-Progress, Prague, Czech Republic. 287 p.

Shouse, P.J., Ayars, E., Šimůnek, J., 2011. Simulating root uptake from a shallow saline groundwater resource. Agricultural Water Management, 98, 784-790.

Shreder, V.R., Vasiliev, I.K., Trunova, T.A., 1977. Hydromodul zoning for calculation of the irrigation rates for cotton under arid environments. In: Proceedings of the 
Middle Asia Research Institute of Irrigation. No. 8. Middle Asia Research Institute of Irrigation, Tashkent, pp. 28-41.

Shultsc, V.L., 1949. Rivers of Middle Asia. State Publishing House of Geographic Literature, Moscow, 196 p. (In Russian.)

Šimůnek, J., Šejna, M., Saito, H., Sakai, M., van Genuchten M.Th., 2008. The HYDRUS-1D Software Package for Simulating the Movement of Water, Heat, and Multiple Solutes in Variably Saturated Media, Version 4.0, HYDRUS Software Series 3. Department of Environmental Sciences, University of California Riverside, Riverside, California, USA, $315 \mathrm{p}$.

Šimůnek, J., van Genuchten, M.Th., Šejna, M., 2016. Recent developments and applications of the HYDRUS computer software packages. Vadose Zone Journal, 15, 7, 25 p., DOI: 10.2136/vzj2016.04.0033.

Smeal, D., Kallsen, C.E., Sammis, T.W., 1991. Alfalfa yield as related to transpiration, growth stage and environment. Irrig. Sci., 12, 79-86.

Sommer, R., Glazirina, M., Yuldashev, T., Otarov, A., Ibraeva, M., Martynova, L., Bekenov, M., Kholov, B., Ibragimov, N., Kobilov, R., Karaev, S., Sultonov, M., Khasanova, F., Esanbekov, M., Mavlyanov, D., Isaev, S., Abdurahimov, S., Ikramov, R., Shezdyukova, L., de Pauw, E., 2013. Impact of climate change on wheat productivity in Central Asia. Agriculture, Ecosystems \& Environment, 178, 78-99.

Soppe, R.W., Ayars, J.E., 2002. Crop water use by safflower in weighing lysimeters. Agricultural water management, 69, 59-71.

Soylu, M.E., Istanbulluoglu, E., Lenters, J.D., Wang, T., 2011. Quantifying the impact of groundwater depth on evapotranspiration in a semi-arid grassland region. Hydrol. Earth Syst. Sci., 15, 787-806. www.hydrol-earth-systsci.net/15/787/2011/doi:10.5194/hess-15-787-2011.

Spoor, M., 1998. The Aral Sea Basin crisis: Transition and environment in former Soviet Central Asia. Development and Change, 29, 409-435.

Stokstad, E., 2010. Could less meat mean more food? Science, $327,810-811$.
Sumochkina, T.E., Konovalova, N.S., Ivanova, D.A., Kapner, D.Ya., Muminov, F.A., Reizvih, O.N., Abdullaev, Kh.M., Gorelysheva, Z.M., Titova, M.M., 1977. Agroclimatic resources of Namangan, Andijan and Fergana provinces (Fergana Valley) of Uzbekistan. Gidrometeoizdat, Leningrad, 194 p. (In Russian.)

Talipov, G.A., 1992. Land resources of Uzebkistan and problems of their rational use. Uzbek Research Institute of Cotton Growing, Tashkent, 232 p. (In Russian.)

Taylor, S.A., Ashcroft, G.M., 1972. Physical Edaphology. W.H. Freeman and Co., San Francisco, pp. 434-435.

Verkaart, S., Munyua, B.G., Mausch, K., Michler, J.D. 2017. Welfare impacts of improved chickpea adoption: A pathway for rural development in Ethiopia? Food Policy, 66, 50-61.

van Genuchten, M.Th., 1980. A closed-form equation for predicting the hydraulic conductivity of unsaturated soils. Soil Sci. Soc. Am. J., 44, 5, 892-898.

Ward, F.A., Booker, J.F., 2003. Economic costs and benefits of instream flow protection for endangered species in an international basin. Journal of the American Water Resources Association, 427-440.

Ward, F.A., Pulido-Velazquez, M., 2008. Water conservation in irrigation can increase water use. PNAS 105, 18215-18220.

Webber, H.A., 2008. Improving irrigated agriculture in the Fergana Valley, Uzbekistan. PhD Thesis. McGill University. $188 \mathrm{p}$.

Wesseling, J.G., Elbers, J.A., Kabat, P., van den Broek, B.J., 1991. SWATRE; Instructions for Input. Internal Note. Winand Staring Centre, Wageningen.

World Bank, 2009. Uzbekistan - First phase of the Ferghana Valley Water Resources Management Project: Resettlement policy framework and specific resettlement action plan. http://documents.worldbank.org/curated/en/2009/07/108492 23/uzbekistan-first-phase-ferghana-valley-water-resourcesmanagement-project-resettlement-policy-frameworkspecific-resettlement-action-plan. (Accessed on 18.12.2014).

Received 7 August 2017 Accepted 20 October 2017

Note: Colour version of Figures can be found in the web version of this article. 